\title{
Water age - a major factor controlling phytoplankton community structure in a reconnected dynamic floodplain (Danube, Regelsbrunn, Austria)
}

\author{
Michael SCHAGERL*, Irene DROZDOWSKI ${ }^{1)}$, David G. ANGELER ${ }^{2)}$, Thomas HEIN ${ }^{3)}$ and Stefan PREINER ${ }^{3)}$ \\ University of Vienna, Department of Marine Biology, Althanstraße 14, A-1090 Vienna, Austria \\ ${ }^{1)}$ Biosphärenpark Wienerwald Management GmbH, Deutschwaldstraße 15/b, A-3002 Purkersdorf, Austria \\ ${ }^{2)}$ Swedish University of Agricultural Sciences, Dep. of Aquatic Sciences and Assessment, Box 7050, S-750 07 Uppsala, Sweden \\ ${ }^{3)}$ Inter-Universitary Cluster for Water Research, Carl Kupelwieser-Promenade 5, A-3293 Lunz/See, Austria and University of \\ Natural Resources and Applied Life Sciences, Vienna, A-1180 Vienna, Austria \\ e-mail corresponding author: michael.schagerl@univie.ac.at
}

\begin{abstract}
The study was carried out during four years that span a gradient in hydrological connectivity between the Danube and its sidearm system at Regelsbrunn (Austria). We evaluated the influences of distinct periods of hydrological connectivity on the phytoplankton community structure itself, but also interferences with biotic processes (including community succession, competition and zooplankton grazing) that may take place within the constraints set by the hydrological disturbance regime. Algal biomass was highly related to the hydrological regime: lowest amounts were detected either during flood events or at long-lasting periods of isolation; on the other hand intermediate connection led to maximum concentrations. During floods and throughout the cold season, Bacillariophyceae were dominating the algal community. Summer and elongated periods of isolation favoured Chlorophyta. Cryptophyta occurred in early autumn after two months disconnection from the main channel, Dinophyta and Cyanoprokaryota were only of minor importance. Multivariate statistical analyses showed that water age was the primary determinant of phytoplankton community structure in the side-arm system. Cluster analyses revealed 7 groups that were characterized by 169 indicator taxa. Groups were dominated by Bacillariophyceae (Nitzschia, Navicula, Cymbella, Fragilaria and Diatoma), while species belonging to the Chloro-, Eugleno- and Dinophyta were less abundant. Non-metric Multidimensional Scaling was used for a comparison of community similarity between the main channel and the side-arm system. During high connectivity temporal trends of phytoplankton similarity in the side-arm tracked closely the community patterns of the Danube which indicated a major influence of the main channel on phytoplankton community structure. During low connectivity the temporal trends of the communities from both sampling stations were less coupled. A Canonical Correspondence Analysis explained $89.7 \%$ of the variance of the species-environment relation. Water age, particulate inorganic matter and dissolved inorganic nitrogen compounds were strongly coinciding with the first axis, whereas particulate nitrogen was mainly related to the second axis. A phytoplankton succession model was developed for the side-arm system. This model emphasizes increased phytoplankton community similarity during high connectivity and short isolation periods and a site-specific community development during low connectivity between the Danube and the side-arm. During prolonged isolation, seasonality gained importance in structuring the plankton community. Biotic interaction (intraguild competition and zooplankton grazing) played an important role in the shifts between successional stages, suggesting that these effects should not be neglected in ecological studies of disturbance-dependent floodplain ecosystems.
\end{abstract}

Key words: hydrology, connectivity, phytoplankton community, floodplain, river

\section{INTRODUCTION}

Floodplains are among the most dynamic, diverse and productive ecosystems of the world (Tockner \& Stanford 2002), and they provide a series of ecosystem services to humans and wildlife (e.g., flood protection, breeding and foraging habitat, biodiversity stores; Middleton 1999). Despite their high environmental value, different forms of anthropogenic stress posed a serious threat to the ecological integrity of floodplains, and by extension, whole riverine ecosystem during the last century.

The lateral dimension of fluvial ecosystems has long been ignored by limnologists (Vannote et al. 1980), but found special recognition in the Flood Pulse Concept (Junk et al. 1989; Johnson et al. 1993; Junk \& Wantzen 2004), which highlights the importance of flood events for floodplain productivity and aquatic habitat diversity (Bayley 1991, 1995). However, many ecological aspects of the lateral connectivity between rivers and their sidearms are only poorly understood and complicated by the environmental stochasticity underlying the hydrological disturbance regime. Some studies documented the effects of flood pulses on the abiotic and biotic environment (e.g., Van den Brink et al. 1993; Baranyi et al. 2002; Hein et al. 2003; Jenkins \& Boulton 2003; Hein et al. 2004a; Gruberts et al. 2007) but phytoplankton communities have been less well studied in these frequently connected sub-systems (Limberger et al. 2004).

A structural characterisation of phytoplankton is an important first step towards our understanding of its functional role in riverine ecosystems. Much of our cherished wildlife, including amphibians and birds, may rely on the productivity of the aquatic food web base in 


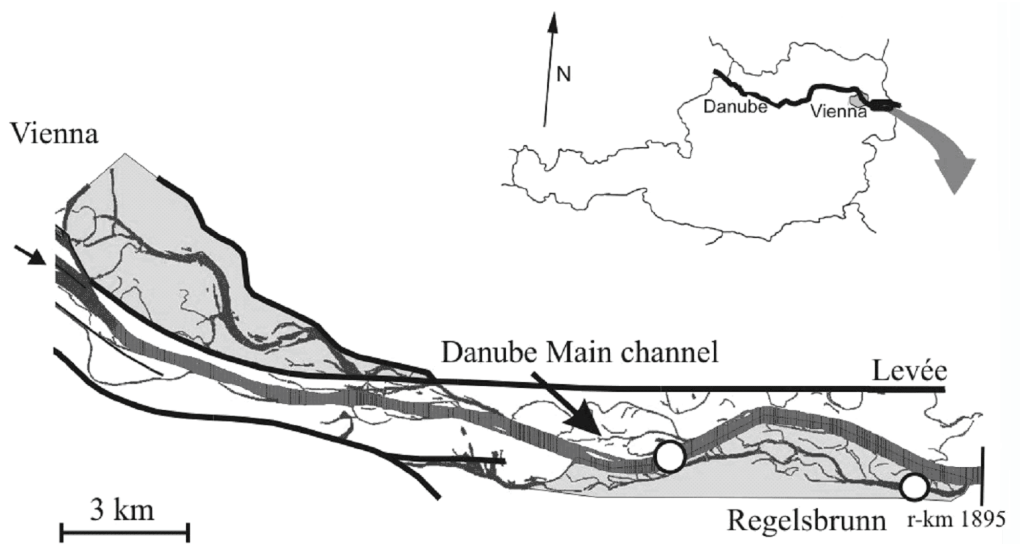

Fig. 1. Map of the floodplain system National Park Donauauen (grey area). Points indicate sampling sites D (Danube main channel) and R (Regelsbrunn r-km 1895). Insert: location within Austria.

floodplains (Jenkins \& Boulton 2007). Because phytoplankton has rapid growth and turnover rates, it may be an ideal candidate to study biological responses to the hydrological disturbance regimes over relatively small temporal scales.

Wetland ecologists have traditionally focused on hydroperiods and flood frequency to define relatively broadly the hydrological disturbance regime of wetlands (Mitsch \& Gosselink 2000). However, riverine wetlands and backwaters are often characterised by permanent hydroperiods, yet the frequency and interval of flood pulses determines the degree of connectivity which in turn influences water residence time (here called water age) in side-arms. The water age could therefore serve as a good predictor of the influence of hydrological disturbance on backwater plankton communities (e.g., Baranyi et al. 2002).

This study was carried out during four years that span a gradient in hydrological connectivity between the Danube and its side-arm system at Regelsbrunn (Austria). We hypothesize that short water age in the sidearm system leads to a dominance of $\mathrm{r}$-strategists like centric diatoms, which are also prevailing in the main channel. During periods of higher water age biotic interactions gain in importance and therefore a more diverse phytoplankton community will be found, including many $K$-strategists. The marked differences of hydrological connectivity between years allowed evaluating the role of hydrological fluctuation on phytoplankton community structure itself, but also the influence of potential biotic processes (including community succession, competition and zooplankton grazing) within the constraints set by the hydrological disturbance regime.

\section{METHODS}

\subsection{Study site}

The side arm of Regelsbrunn is located $25 \mathrm{~km}$ downstream of Vienna on the southern bank of the river Danube. It is part of the "Nationalpark Donauauen", which protects the biggest remnant backwater system in middle Europe. During the last 120 years the hydrological disturbance regime of this backwater has been severely altered. River channelisation resulted in a $60 \%$ disconnection of the side arm from the main stream and drainage practises caused a $23 \%$ loss of riverine forests (Tockner et al. 1999).

In the course of the 'Danube Restoration Project' the side-arm system of Regelsbrunn was reconnected to the Danube in 1997 (Hein et al. 1999; Schiemer et al. 1999; Tockner et al. 1999). While the backwater system was connected at mean water levels of $+0.5 \mathrm{~m}$ prior to restoration, surface flood pulses from the Danube onto the wetland system are nowadays guaranteed beyond mean mainstream water levels of $-0.5 \mathrm{~m}$. The restorative intervention increased the lateral connectivity between the river and the side arm which lasts on average $220 \mathrm{~d}$ $\mathrm{y}^{-1}$. It also affected hydrogeomorphological dynamics and increased the availability of semi-aquatic habitats (Baranyi et al. 2002).

During this research, we sampled one site $(\mathrm{R})$ in the backwater system at the weir of Regelsbrunn during periods of high, medium and low connectivity. To compare phytoplankton dynamics with the main-channel we sampled an additional point close to the right bank (D; Fig. 1).

\subsection{Sampling design}

Data from the R-sampling site were obtained in 1997 (March to December), 1998 (May to September), 1999 (April to July), and 2003 (March to October). Dpoint data were available for 1999 and 2003. Samples were taken usually at intervals of two weeks (around 17 times per year) following the methods described by Wittmann (2001), Hein et al. (2004b), and Schagerl et al. (2004). Briefly, temperature, electrical conductivity, dissolved oxygen ( $\mathrm{mg} \mathrm{L}^{-1}$ and relative saturation in \%) and the vertical profile of light intensity ( $\mu \mathrm{mol}$ photons PAR $\mathrm{m}^{-2} \mathrm{~s}^{-1}$ ) were measured in the field (WTW Cond 330i, WTW Oxi 330i, Licor LI 1000). Water samples were collected $20 \mathrm{~cm}$ below the surface in $10 \mathrm{~L}$ poly- 
ethylene bottles. In the laboratory, part of the sample was immediately filtered through pre-combusted Whatman GF/F filters. The filters were used for determination of particulate matter (PM) and particulate inorganic matter (PIM). Particulate organic matter (POM) was calculated by subtraction of PIM from PM. Using standard methods (Strickland \& Parsons 1972; Goltermann et al. 1978; A.P.H.A. 1995), total alkalinity, $\mathrm{pH}$ and inorganic nutrient concentrations (chloride, silica, dissolved fractions of nitrogen and phosphorus) were analyzed in the filtrate. Total nitrogen (TN) and phosphorus (TP) were measured in unfiltered samples; particulate fractions were calculated from total minus dissolved components.

Part of the sample was filtered through Whatman $\mathrm{GF} / \mathrm{C}$ filters for pigment analysis. Subsequently, filters were frozen at $-20{ }^{\circ} \mathrm{C}$. For extraction, filters were ground in cold $90 \%$ acetone and stored at $4{ }^{\circ} \mathrm{C}$ for $12 \mathrm{~h}$. After centrifugation, part of the supernatant was used for determination of chlorophyll-a (Chl- $a$; Lorenzen 1967; spectrophotometer Hitachi U-2100). Additionally, pigments were separated using HPLC (Merck-Hitachi HPLC System; column: Merck-Superspher RP-18 250/4; precolumn: Merck-Lichrospher RP-8 encappped; ternary gradient with distilled water, acetone and acetonitril; prederivatisation with tetrabutylammoniahydroxide) (Wright et al. 1991). Peaks were detected at $440 \mathrm{~nm}$ (Schagerl 1993; Schagerl et al. 1996). For estimation of the algal class contribution to total Chl- $a$, we used ratios of Chl- $a$ to class specific pigments (Bacillariophyceae and Chrysophyceae: fucoxanthin; Cyanoprokaryota: echinenone; Chlorophyta, Euglenophyta + Prasinophyceae: Chl- $b$, Dinophyta: peridinin, Cryptophyta: alloxanthin). Ratios were obtained from pure cultures at different light and nutrient conditions in previous investigations (Wilhelm et al. 1991; Soma et al. 1993; Schagerl \& Donabaum 2003; Schagerl et al. 2003). The contribution of each algal class to total Chl- $a$ was determined and finally the relative abundance on a basis of total Chl- $a$ of each class was calculated.

Two types of phytoplankton samples were taken at both sites for quantitative and qualitative analyses. For phytoplankton biomass estimations, water was collected in brown-glass bottles and preserved with Lugol's solution. Using an inverted microscope (Nikon), phytoplankton taxa were identified to the lowest possible taxonomic level, counted and cell dimensions were measured (Utermöhl 1958). Biovolume was calculated using geometric shapes (Höhn et al. 1998) and converted into algal fresh mass $\left(1 \mu \mathrm{m}^{3}=10^{-9} \mathrm{mg}\right.$ fresh mass). For identification of living material, phytoplankton samples were taken with a plankton net (mesh size $30 \mu \mathrm{m}$ ). For diatom determination, part of the samples was treated by either dry combustion (burning off organic matter from dried samples on cover slides) or with acids (first in concentrated $\mathrm{HCl}$ for $24 \mathrm{~h}$, then in a mixture of concentrated $\mathrm{H}_{2} \mathrm{SO}_{4}$ and $\mathrm{HNO}_{3}$ acid $=3: 1$ for
$24 \mathrm{~h}$ ). After rinsing with distilled water, specimens were embeded in Naphrax. Taxa were identified with a Polyvar microscop (Reichert-Jung) using the identification keys of Geitler (1932), Anagnostidis \& Komarek (1988), Komarek \& Anagnostidis (1999) (Cyanoprokaryota), Bourelly (1970) (Cryptophyta), Starmach (1985) (Chrysophyceae), Krammer \& Lange-Bertalot (1986, 1988, 1991a, b) (Bacillariophyceae), HuberPestalozzi (1955), Kusel-Fetzmann (2002) (Euglenophyta), Popovsky and Pfiester (1990) (Dinophyta), Ettl (1983) and Komarek \& Fott (1983) (Chlorophyta s.1.). Relative abundances were estimated on an arbitrary scale from 1 (sporadic) to 5 (very abundant).

Water age at the R-site was calculated using a hydrological model which has been developed for the side-arm system of Regelsbrunn (Baranyi et al. 2002). Water age is a parameter for the average residence time of the waterbody in the backwater system, water of the main channel is set to 0 . Daily changes of the floodplains waterbody were calculated considering both inflow and outflow. Daily water levels of the main channel were provided by the Federal Waterway Agency.

\subsection{Statistical analyses}

A principal components analysis (PCA) with Varimax factor rotation was carried out for interpreting the abiotic environment. PIM was used as a surrogate of the underwater light conditions due to its strong relationship with the light attenuation coefficient $\left(r^{2}=0.7 ; p<0.01\right.$, $\mathrm{n}=50$ ). PIM, POM, particulate nitrogen (Npart), particulate phosphorus (Ppart), dissolved inorganic nitrogen (DIN), dissolved phosphorus (DP), conductivity, water age and Chl- $a$ were used for analysis. PIM, POM, water age and Chl- $a$ were ln-transformed.

Phytoplankton samples were classified using cluster analysis (CA). Relative species abundance estimations were used in the analysis because they provided a higher taxonomic resolution compared with biomass data. This allowed taking species into account that would otherwise be unidentifiable in fixed sample enumerations. A dissimilarity matrix was calculated using Sørensen Distance, which is an effective distance measure for community data (Mc Cune \& Grace 2002). Flexible beta linkage $(B=-0.25)$ served as group linkage method. We used an Indicator Species Analysis (ISA) to determine the optimum number of groups (Mc Cune \& Grace 2002). After clustering the sites, indicator values for each species were calculated for various numbers of groups. The average of the significance values of all species was calculated. The level of grouping resulting in the lowest average p-value was interpreted as the most meaningful number of groups and used for subsequent analyses.

ISA was carried out to identify species that are characteristic of the groups revealed by CA (Dufrêne \& Legendre 1997; Limberger et al. 2004; Mc Cune \& 
Tab. 1 Means, minima (min) and maxima $(\max )$ of environmental variables measured at sampling site R. Water age, Temperature, Conductivity, $\mathrm{pH}$, Alkalinity, $\mathrm{O}_{2}$ (dissolved oxygen), $\mathrm{PM}$ (particulate matter), POM (particulate organic matter), PIM (particulate inorganic matter), Ppart (particulate phosphorus), DP (dissolved phosphorus), $\mathrm{P}_{-} \mathrm{PO}_{4}$ (phosphorus of $\mathrm{PO}_{4}$ ), DOP (dissolved organic phosphorus), Npart (particulate nitrogen), $\mathrm{N}-\mathrm{NO}_{3}\left(\right.$ nitrogen of $\left.\mathrm{NO}_{3}\right), \mathrm{N}^{-} \mathrm{NO}_{2}$ (nitrogen of $\mathrm{NO}_{2}$ ), $\mathrm{N}-\mathrm{NH}_{4}$ (nitrogen of $\mathrm{NH}_{4}$ ), DIN (dissolved inorganic nitrogen), DON (dissolved organic nitrogen), $\mathrm{Cl}$ (Chloride), Chl- $a$ (chlorophyll- $a$ ).

\begin{tabular}{|c|c|c|c|c|c|c|c|c|c|c|c|c|}
\hline & \multicolumn{3}{|c|}{1997} & \multicolumn{3}{|c|}{1998} & \multicolumn{3}{|c|}{1999} & \multicolumn{3}{|c|}{2003} \\
\hline & mean & $\min$ & $\max$ & mean & $\min$ & $\max$ & mean & $\min$ & $\max$ & mean & $\min$ & $\max$ \\
\hline Water age (d) & 9.7 & 0.1 & 52.6 & 3.9 & 0.2 & 23.0 & 0.3 & 0.3 & 0.8 & 30.4 & 1.2 & 89.7 \\
\hline Temperature $\left({ }^{\circ} \mathrm{C}\right)$ & 13.6 & 3.5 & 21.8 & 15.8 & 0.3 & 21.5 & 14.4 & 14.4 & 20.0 & 17.3 & 6.1 & 26.8 \\
\hline Conductivity $\left(\mu \mathrm{S} \mathrm{cm}^{-1}\right)$ & 420 & 293 & 495 & 384 & 309 & 571 & 366 & 366 & 420 & 460 & 397 & 513 \\
\hline $\mathrm{pH}$ & 8.4 & 8.2 & 8.8 & 8.3 & 7.8 & 8.6 & 8.4 & 8.4 & 8.6 & 8.4 & 8.3 & 8.6 \\
\hline Alkalinity $\left(\mathrm{meq} \mathrm{L}^{-1}\right)$ & 3.2 & 1.1 & 4.0 & 2.9 & 2.3 & 3.6 & 2.9 & 2.9 & 3.4 & 3.6 & 3.0 & 4.5 \\
\hline $\mathrm{O}_{2}\left(\mathrm{mg} \mathrm{L}^{-1}\right)$ & 11.6 & 8.2 & 15.8 & 10.6 & 8.1 & 15.5 & 10.3 & 10.3 & 11.8 & 11.8 & 8.8 & 16.6 \\
\hline $\mathrm{PM}\left(\mathrm{mg} \mathrm{L}^{-1}\right)$ & 23.4 & 8.0 & 171.1 & 25.2 & 8.5 & 50.6 & 58.3 & 58.3 & 172.8 & 12.9 & 2.8 & 27.6 \\
\hline POM $\left(\mathrm{mg} \mathrm{L}^{-1}\right)$ & 5.5 & 2.9 & 18.5 & 5.1 & 3.3 & 8.8 & 5.7 & 5.7 & 11.5 & 4.5 & 1.2 & 9.7 \\
\hline PIM $\left(\mathrm{mg} \mathrm{L}^{-1}\right)$ & 17.9 & 3.2 & 152.6 & 20.1 & 4.9 & 45.4 & 52.6 & 52.6 & 163.3 & 8.4 & 1.5 & 25.1 \\
\hline Ppart. $\left(\mu \mathrm{g} \mathrm{L}^{-1}\right)$ & 47.3 & 3.0 & 284.0 & 44.9 & 17.0 & 62.0 & 73.9 & 73.9 & 146.0 & 37.6 & 10.0 & 77.0 \\
\hline $\mathrm{DP}\left(\mu \mathrm{g} \mathrm{L}^{-1}\right)$ & 17.1 & 4.0 & 54.0 & 22.3 & 6.0 & 40.0 & 20.9 & 20.9 & 33.0 & 11.0 & 6.0 & 29.0 \\
\hline $\mathrm{P}^{-\mathrm{PO}_{4}}\left(\mu \mathrm{g} \mathrm{L}^{-1}\right)$ & 11.6 & 0.0 & 54.0 & 16.1 & 0.0 & 38.0 & 17.4 & 17.4 & 29.0 & 4.0 & 0.0 & 27.0 \\
\hline $\operatorname{DOP}\left(\mu \mathrm{g} \mathrm{L}^{-1}\right)$ & 5.5 & 0.0 & 32.0 & 6.2 & 1.0 & 12.0 & 3.5 & 3.5 & 5.0 & 7.0 & 2.0 & 11.0 \\
\hline Npart. $\left(\mu \mathrm{g} \mathrm{L}^{-1}\right)$ & 182 & 35 & 558 & 151 & 2 & 256 & 208 & 208 & 433 & 228 & 9 & 637 \\
\hline $\mathrm{N}-\mathrm{NO}_{3}\left(\mu \mathrm{g} \mathrm{L}^{-1}\right)$ & 1066 & 98 & 3152 & 1051 & 69 & 1771 & 1647 & 1647 & 2181 & 600 & 44 & 2350 \\
\hline $\mathrm{N}-\mathrm{NO}_{2}\left(\mu \mathrm{g} \mathrm{L}^{-1}\right)$ & 15.6 & 1.7 & 39.0 & 18.0 & 0.8 & 31.9 & 24.9 & 24.9 & 33.4 & 17.6 & 0.4 & 70.0 \\
\hline $\mathrm{N}-\mathrm{NH}_{4}\left(\mu \mathrm{g} \mathrm{L}^{-1}\right)$ & 55 & 0 & 188 & 100 & 20 & 196 & 90 & 90 & 133 & 256 & 0 & 148 \\
\hline $\operatorname{DIN}\left(\mu \mathrm{g} \mathrm{L}^{-1}\right)$ & 1136 & 116 & 3310 & 1169 & 154 & 1825 & 1736 & 1736 & 2263 & 643 & 523 & 2391 \\
\hline $\mathrm{DON}\left(\mu \mathrm{g} \mathrm{L}^{-1}\right)$ & 132 & 44 & 269 & 102 & 38 & 164 & 180 & 180 & 241 & 222 & 147 & 276 \\
\hline $\mathrm{Cl}\left(\mathrm{mg} \mathrm{L}^{-1}\right)$ & 12.7 & 6.0 & 17.0 & 12.3 & 10.0 & 18.0 & 13.4 & 13.4 & 13.4 & 16.8 & 14.0 & 19.0 \\
\hline Chl- $a\left(\mu \mathrm{g} \mathrm{L}^{-1}\right)$ & 22.9 & 0.8 & 62.5 & 19.9 & 5.7 & 57.7 & 17.0 & 17.0 & 51.0 & 21.8 & 3.0 & 57.0 \\
\hline
\end{tabular}

Grace 2002). A species is regarded as highly indicative of a particular group when it is mainly found in that single group and is present in a large number of its sample units. The mean abundance of that species in a particular group compared to all groups is calculated as a measure of specificity. The proportion of sites in this group which contain that species serves as a measure of fidelity. Multiplication of the two values gives the indicator value; the result is expressed as a percentage. The significance of the indicator values was tested using a Monte Carlo test with 1000 permutations. Here, the probability of type I error is the proportion of times that the highest indicator value from the randomized data set equals or exceeds the highest indicator value from the actual data set. The null hypothesis is that the highest indicator value is not larger than would be expected by chance (i.e. that the species has no indicator value).

To test the relationship between phytoplankton community structure and environmental conditions in the side arm, a canonical correspondence analysis (CCA, lengths of gradients longer than two times of standard deviation) was run using indicator species of each group that showed the highest indicator level and the seven significant environmental variables out of the 9 variables which were used for PCA. A manual forward selection and a Monte Carlo test with 499 permutations was used to test for significance of the first four axes.

Non-metric multidimensional scaling (MDS) analyses with 500 permutations were used to display community similarity and temporal dynamics of both sampling stations during two hydrological contrasting years (1999 with a high connectivity and 2003 with a low connectivity) in multivariate ordination space. This multivariate technique also allowed assessing the degree of influence of the phytoplankton community of the main channel on the structure of phytoplankton in the backwater system. A dissimilarity matrix using Bray-Curtis distances was calculated from the relative species abundances for each station. This nonlinear method ranks points such that distance in ordination space represents community similarity (ter Braak 1995). The correspondence of the ordination diagram to the similarity distances is described by a stress value where 0 is a perfect fit. The NMDS analyses used two ordination axes to track time trends in ordination space. All data were fourth root transformed prior to analysis to down-weight the importance of species from dominant abundance classes. To reveal environmental effects on community dissimilarity, we used Pearson correlation analysis to relate NMDS dimensions to water quality variables. The relative importance of selected indicator species was superimposed to the ordination to discern environmental situations based on biotic indicators.

PCA and correlation analyses were performed using SPSS 12.0 for windows, CA and ISA were calculated with PC-ORD for Windows 4.0 (Mc Cune \& Mefford 1999) and CCA was carried out with CANOCO for Windows 4.5 (ter Braak \& Smilauer 2002). NMDS analyses were run using the Primer 6 software (PrimerE Ltd, Plymouth, UK). 


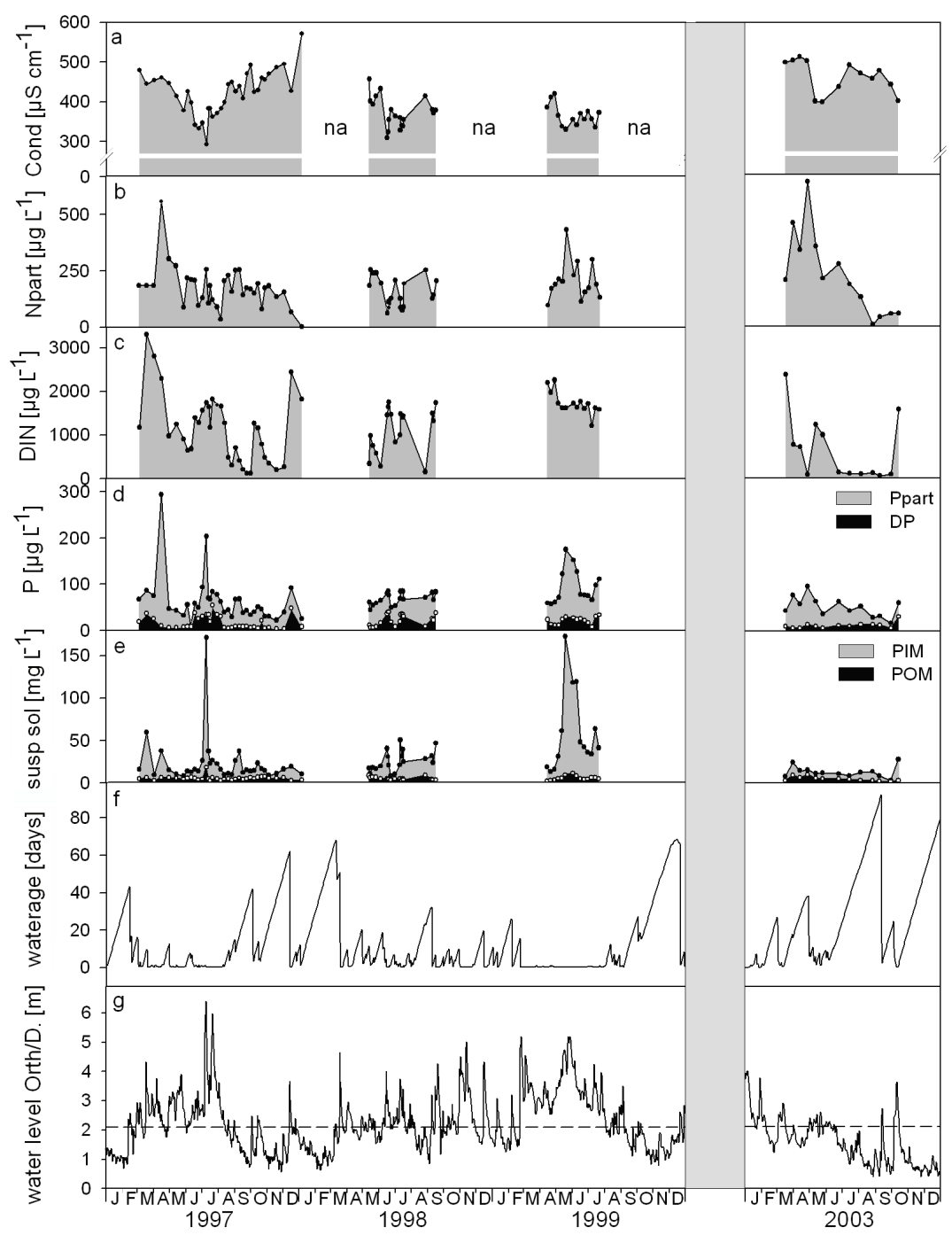

Fig. 2. (a)-(f) Temporal trends of conductivity (Cond), particulate nitrogen (Npart), dissolved inorganic nitrogen (DIN), dissolved phosphorus (DP) \& particulate phosphorus Ppart), particulate organic (POM) \& inorganic matter (PIM) and water age at Regelsbrunn (R). (na) no analyses (g) Water level of the River Danube at Orth. Dashed line shows meanwater $-0.5 \mathrm{~m}$.

\section{RESULTS}

\subsection{Environmental variables}

During the years 1997 - 1999 and 2003 the side-arm of Regelsbrunn was connected to the main channel of the Danube on 643 days which is equivalent to $44 \%$ of the period. However, the time of connection varied between years (Fig. 2g). 1997 showed distinct periods of connection lasting for up to 71 days and included three flood pulses between March and July. The rest of the year was characterised by only a few periods of short connections ( $\max 6$ d). 1998 was characterized by some periods of connection from the middle of March until the end of the year. Highest connectivity was observed in 1999 after restoration measures took place. The backwater was connected to the mainstream for 162 days without interruption and received 4 flood pulses. 2003 showed no flood pulses and was characterized by a long period of disconnection $(\max 85 \mathrm{~d})$.
Means, minima and maxima of abiotic variables for each year are listed in table 1, temporal variability of selected abiotic variables is shown in figure 2. Connectivity and water age strongly influenced nutrient availability, conductivity and PM amounts. High connectivity during flood pulses led to low conductivity (min $293 \mu \mathrm{S} \mathrm{cm}^{-1}$ ), high concentrations of DP (max $54 \mu \mathrm{g}$ $\left.\mathrm{L}^{-1}\right)$, DIN $\left(\max 3310 \mu \mathrm{g} \mathrm{L}^{-1}\right)$ and PM $(\max 172.8 \mathrm{mg}$ $\mathrm{L}^{-1}$, PIM max $163.3 \mathrm{mg} \mathrm{L}^{-1}$, POM max $\left.18.5 \mathrm{mg} \mathrm{L}^{-1}\right)$. By contrast, electrical conductivity increased to $571 \mu \mathrm{S} \mathrm{cm}-$ 1 during periods of isolation while DP ( $\min 4.0 \mu \mathrm{g} \mathrm{L}^{-1}$ ), DIN (min $52.5 \mu \mathrm{g} \mathrm{L}^{-1}$ ) and PM decreased (min $2.8 \mathrm{mg}$ $\mathrm{L}^{-1}$, PIM min $1.5 \mathrm{mg} \mathrm{L}^{-1}$, POM min $1.2 \mathrm{mg} \mathrm{L}^{-1}$ ). For Ppart and Npart, patterns were more complicated. The concentrations of these compounds were highest during flood pulses but decreased during connectivity phases when water age increased. During isolation phases, Npart and Ppart rose again, but declined after isolation periods exceeding $37 \mathrm{~d}$. 


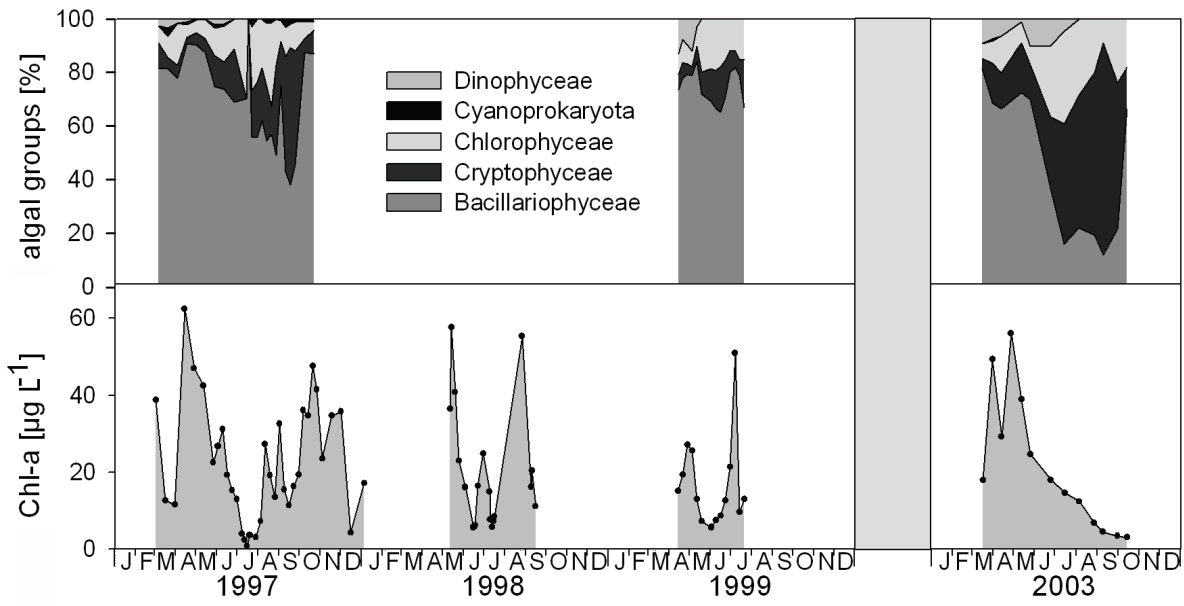

Fig. 3. Temporal trends of chlorophyll- $a$ and algal class distribution (HPLC) at sampling site R.

PCA led to a 3-factor model (Tab. 2) that explained $80 \%$ of the total variance. $70 \%$ of environmental variation was described by the first two axes. The first axis was highly correlated with POM, PIM, Npart and Ppart, and thus reflects turbidity. DIN and water age represent the second axis "hydrology", while DP (negative correlation) and Chl- $a$ define the third axis that indicates "algal biomass".

Tab. 2. Principal component analysis using 9 environmental variables. Factor loadings of PC1-3 exceeding 0,6 are bold. Variance of data explained by components are shown in brackets.

\begin{tabular}{lccc}
\hline & PC1 $(42.5 \%)$ & PC2 $(27.5 \%)$ & PC3 (10.3\%) \\
\hline POM & $\mathbf{0 . 8 8 8}$ & -0.039 & 0.050 \\
PIM & $\mathbf{0 . 7 8 8}$ & 0.244 & -0.450 \\
Npart & $\mathbf{0 . 7 2 5}$ & 0.097 & 0.556 \\
ln Ppart & $\mathbf{0 . 6 7 1}$ & 0.484 & 0.120 \\
DIN & 0.051 & $\mathbf{0 . 9 5 8}$ & -0.053 \\
ln water age & -0.239 & $\mathbf{- 0 . 8 2 3}$ & 0.407 \\
ln Chl- $a$ & 0.184 & -0.075 & $\mathbf{0 . 8 6 6}$ \\
DP & 0.016 & 0.568 & $\mathbf{- 0 . 6 6 1}$ \\
Cond & -0.287 & -0.470 & 0.581 \\
\hline
\end{tabular}

\subsection{Phytoplankton}

The course of Chl- $a$ showed a complex pattern that was strongly related to hydrology (Fig. 3). Lowest values $<10.0 \mu \mathrm{g} \mathrm{L}^{-1}$ were measured during flood events and periods of high connectivity with water age $<0.3 \mathrm{~d}$ (min $0.8 \mu \mathrm{g} \mathrm{L}^{-1}$ ) and during periods of long-lasting isolation $\left(6.8 \mu \mathrm{g} \mathrm{L}^{-1}\right.$, water age $\left.77.1 \mathrm{~d}\right)$. Highest values $>40 \mu \mathrm{g}$ $\mathrm{L}^{-1}$ were observed at intermediate water age (max 57.0 $\mu \mathrm{g} \mathrm{L}^{-1}$, water age $38.1 \mathrm{~d}$ ) or several days after isolation phases (max $57.7 \mu \mathrm{g} \mathrm{L}^{-1}$, water age $1.2 \mathrm{~d}$ ).

The contribution of major algal groups to the phytoplankton community is shown in figure 3 . Results were taken from HPLC data which are significantly correlated with counting data for the classes Bacillariophyceae $\left(r^{2}=0.59\right)$, Cryptophyta $\left(r^{2}=0.51\right)$ and Chlorophyta $\left(r^{2}=0.38\right)$. Diatoms were the dominant algal class with maxima during flood events, spring, autumn and winter (max 91\%). From May to autumn, Chlorophyta became important in 1997 and 2003 with a maximum in summer 2003 during a long phase of isolation (max $35 \%$ ). In 1999, the development of Chlorophyta did not reach these values because of high connectivity during the whole summer. Cryptophyta showed their maxima in September after a longer period of isolation in 1997 (max $51 \%, 16 \mathrm{~d}$ of isolation) and $2003(\max 79.9 \%, 82$ d disconnection). Dinophyta only appeared in spring (max $13 \%)$. Cyanoprokaryota were rarely found and showed a maximum value of 3\% during a period of isolation.

CA using relative species abundance estimations resulted in 7 groups of sampling dates (Fig. 4). 2003 was divided into two groups that differed mainly in season. Group 1 comprised sampling dates from March to May, and group 2 from July to October. 1999 was indicated as group 3. All dates of 1997 and 1998 were splitted into groups 4 to 7 with different periods of connectivity and season: group 4 comprised sampling dates mostly from May to July and showed connection of the backwater to the main channel. Sampling dates of group 5 were dominated by similar conditions but had their emphasis during July and August. Group 6 displayed sampling dates of isolation during August and September, group 7 during autumn and winter.

In total 169 significant indicator species were identified by ISA, 50 for group 1, 52 for group 2, 46 for group 3,5 for group 4, no one for group 5, 12 for group 6 and 4 for group 7. Species with high and significant indicator values are listed in table 3 . These 29 species were related to 7 environmental variables in the CCA (Tab. 5, Figs 5, 6). Most groups were dominated by taxa belonging to the Bacillariophyceae (Nitzschia, Navicula, Cymbella, Fragilaria and Diatoma), while species of the Chloro-, Eugleno- and Dinophyta were less present. A comparison with correspondence analysis showed a very similar pattern of the species distribution indicating that most important variables were considered in the constrained ordination (data not shown). 


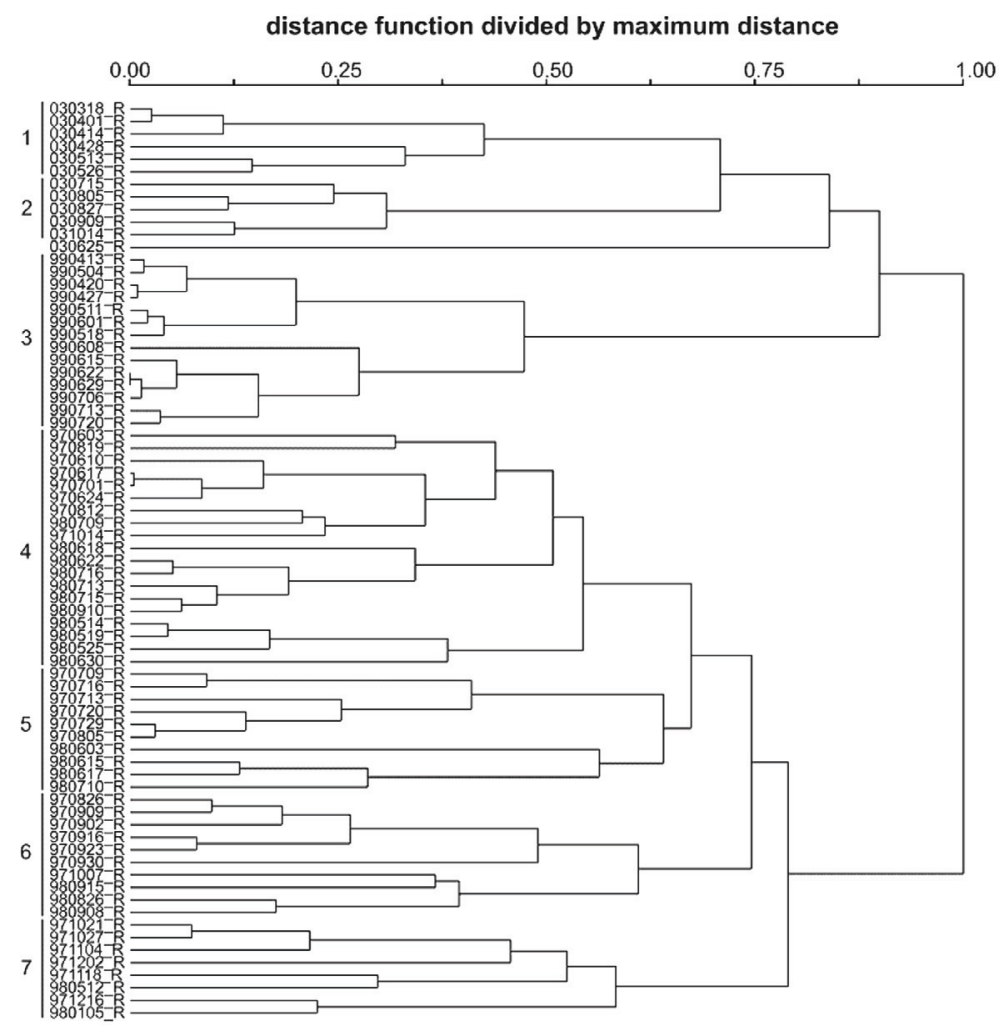

Fig. 4. Dendrogram based on relative species abundance estimations (Sørensen Distance, flexible beta linkage). Numbers on the left indicate groups of sampling dates.

Tab. 3. Indicator values of 29 indicator species determined by Indicator Species Analysis. The five most indicative species for each group are shown. For group 7 only four and for group 5 no indicator species could be identified. Indicator values range from 0 to $100 \%$.

\begin{tabular}{|c|c|c|c|}
\hline Species & Abbreviation & Group & Indicator value \\
\hline Cyclotella radiosa (Grunow) Lemmermann & Cyclradi & 1 & 87.0 \\
\hline Cymbella silesiaca Bleisch & Cymbsile & 1 & 76.3 \\
\hline Stephanodiscus medius (Hakansson 1986) & Stepmedi & 1 & 71.4 \\
\hline Stephanodiscus minutulus (Kützing) Cleve \& Möller & Stepminu & 1 & 69.4 \\
\hline Peridinium sp. Ehrenberg & Perispec & 1 & 67.2 \\
\hline Navicula pseudanglica Lange-Bertalot & Navipseu & 2 & 90.6 \\
\hline Oocystis marsonii Lemmermann & Oocymars & 2 & 80.0 \\
\hline Pediastrum tetras (Ehrenberg) Ralfs & Peditetr & 2 & 76.0 \\
\hline Actinocyclus normanii (Gregory ex Greville) Hustedt & Actinorm & 2 & 72.1 \\
\hline Achnanthes minutissima Kützing 1833 & Achnminu & 2 & 70.8 \\
\hline Nitzschia fonticola Grunow ex Cleve \& Möller & Nitzfont & 3 & 100.0 \\
\hline Nitzschia recta Hantzsch ex Rabenhorst & Nitzrect & 3 & 100.0 \\
\hline Nitzschia dissipata (Kützing) Grunow & Nitzdiss & 3 & 92.9 \\
\hline Nitzschia linearis (Agardh) W.Smith & Nitzline & 3 & 92.0 \\
\hline Nitzschia sublinearis Hustedt & Nitzsubl & 3 & 85.7 \\
\hline Chlamydomonas sp. Ehrenberg & Chlaspec & 4 & 44.7 \\
\hline Nitzschia fruticosa Hustedt & Nitzfrut & 4 & 36.9 \\
\hline Pandorina morum (O.F.Müller) Bory & Pandmoru & 4 & 35.0 \\
\hline Schroederia setigera (Schröder) Lemmermann & Schrseti & 4 & 24.0 \\
\hline Schroederia robusta Korsikov & Schrrobu & 4 & 23.6 \\
\hline Acanthoceras zachariasii (Brun) Simonsen & Acanzach & 6 & 48.9 \\
\hline Euglena oxyuris Schmarda & Eugloxyu & 6 & 40.0 \\
\hline Navicula sp. Bory de St. Vincent & Navispec & 6 & 39.6 \\
\hline Euglena tripteris (Dujardin) Klebs & Eugltrip & 6 & 35.3 \\
\hline Euglena acus Ehrenberg & Euglacus & 6 & 34.3 \\
\hline Cyclotella sp. Brebisson & Cyclspec & 7 & 40.2 \\
\hline Aulacoseira sp. Thwaites & Aulaspec & 7 & 39.5 \\
\hline Cymbella sp. Agardh & Cymbspec & 7 & 25.0 \\
\hline Asterionella formosa Hassall 1850 & Asteform & 7 & 21.2 \\
\hline
\end{tabular}


Tab. 4. Summary statistics of the DCCA.

\begin{tabular}{lcccc}
\hline & Axis 1 & Axis 2 & Axis 3 & Axis 4 \\
\hline$p$-value & 0.002 & 0.002 & 0.002 & 0.240 \\
Eigenvalues & 0.411 & 0.322 & 0.230 & 0.087 \\
Species-environment correlations & 0.835 & 0.775 & 0.707 & 0.652 \\
Cumulative \% variance of species-environment relation & 36.7 & 65.49 & 85.9 & 93.7 \\
Species data & 11.9 & 21.2 & 27.8 & 30.3 \\
Sum of all eigenvalues & 3.463 & & & \\
Test of significance of all canonical axes: $p$-value & 0.002 & & & \\
\hline
\end{tabular}

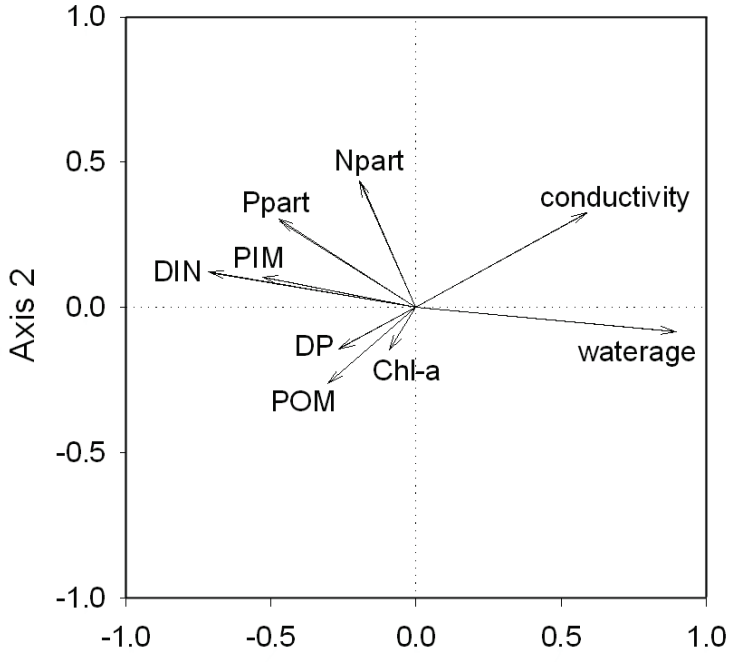

Axis 1

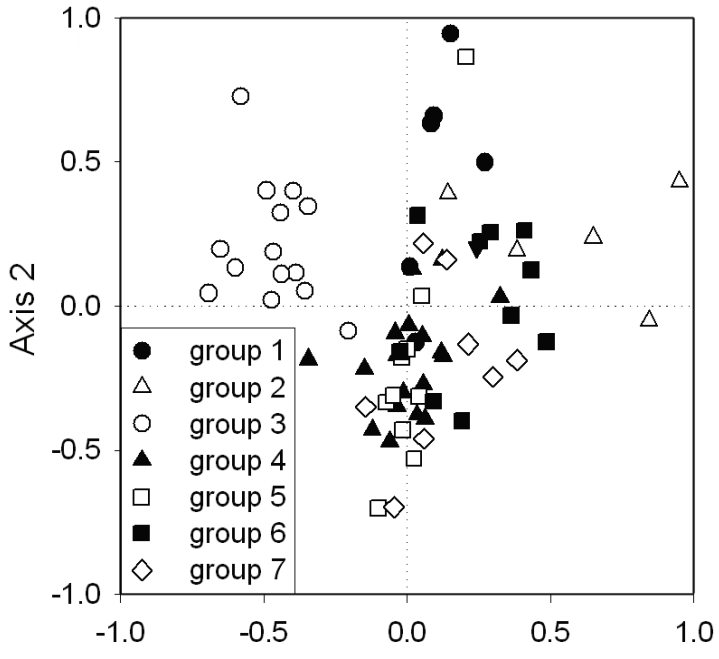

Axis 1

Fig. 5. CCA ordination diagram of environmental variables (left) and sample units (right). Groups identified by cluster analysis are indicated with symbols.

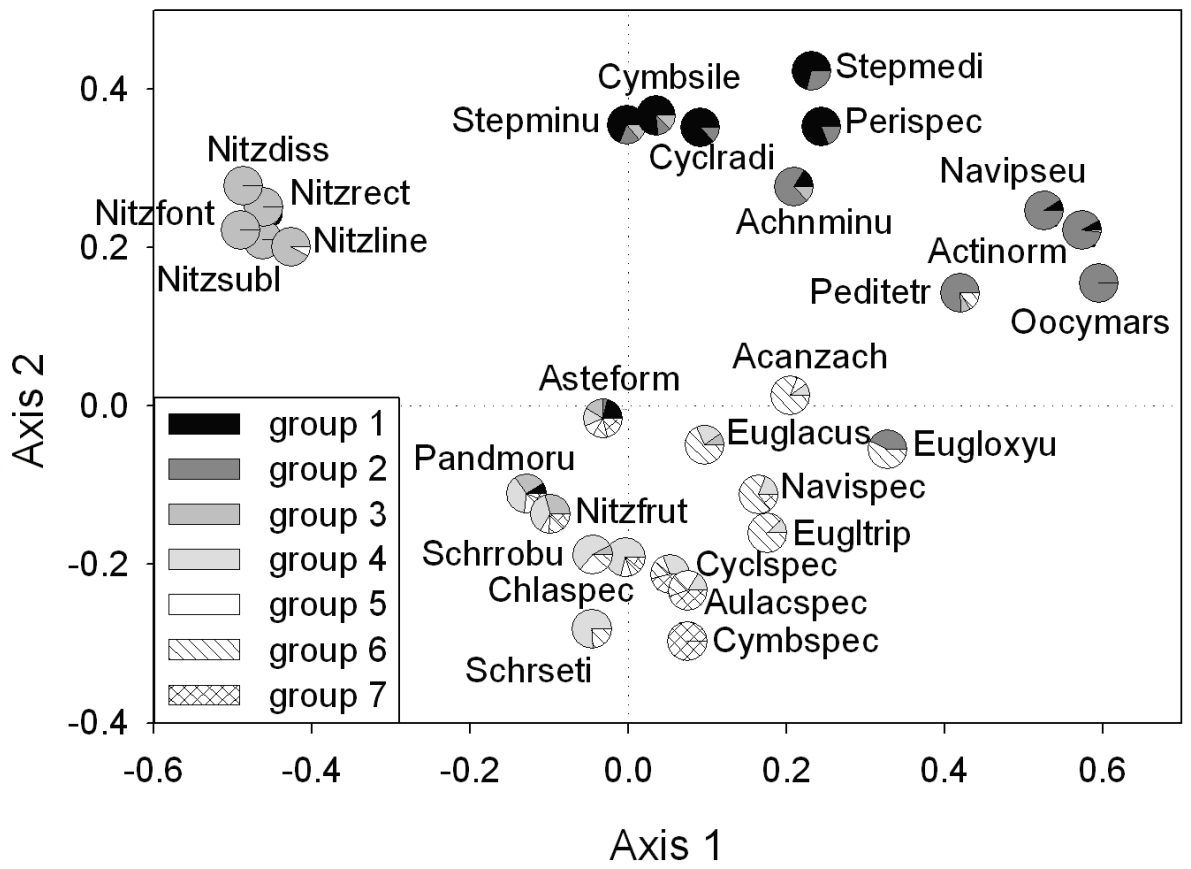

Fig. 6. Positions of 29 indicator species relative to the first two canonical axes. Pie charts show relative abundances in the seven groups. For abbreviations of species see table 3. 
Tab. 5. Standardised environmental optima of the 29 indicator species as determined by CCA. Values higher 0.4 and lower -0.4 are bold for a better visualization of high loadings. Abbreviations of environmental factors and species see table 1 and 3, respectively.

\begin{tabular}{|c|c|c|c|c|c|c|c|c|}
\hline Taxon & Group & POM & PIM & Npart & DIN & Cond & Inchla & lnwaterage \\
\hline Cyclradi & 1 & 0.19 & -0.46 & 13.39 & 0.00 & 0.65 & 0.50 & 0.56 \\
\hline Cymbsile & 1 & 0.16 & -0.35 & 11.16 & -0.01 & 0.82 & 0.53 & 0.44 \\
\hline Perispec & 1 & -0.12 & -0.53 & 0.88 & -0.33 & 0.93 & 0.29 & 0.86 \\
\hline Stepmedi & 1 & -0.07 & -0.48 & 0.96 & -0.12 & 11.27 & 0.30 & 0.83 \\
\hline Stepminu & 1 & 0.34 & -0.13 & 11.56 & -0.03 & 0.73 & 0.48 & 0.37 \\
\hline Achnminu & 2 & -0.41 & 0.24 & -0.29 & -0.36 & 0.48 & -0.78 & 0.44 \\
\hline Actinorm & 2 & -0.96 & -0.34 & -0.89 & -0.98 & 0.85 & -0.95 & 11.90 \\
\hline Navipseu & 2 & -10.89 & -0.38 & -0.88 & -0.92 & 0.72 & -10.96 & 10.58 \\
\hline Oocymars & 2 & -1.00 & -0.42 & -0.90 & -13.13 & 0.96 & -0.85 & 13.65 \\
\hline Peditetr & 2 & -0.67 & -0.17 & -0.52 & -0.89 & 0.48 & -0.54 & 0.87 \\
\hline Nitzdiss & 3 & 0.00 & 1.00 & 0.21 & 10.91 & -0.66 & -0.14 & -11.43 \\
\hline Nitzfont & 3 & 0.21 & 12.69 & 0.25 & 0.97 & -0.79 & -0.27 & -11.59 \\
\hline Nitzline & 3 & 0.02 & 10.28 & 0.12 & 10.58 & -0.75 & -0.28 & -11.53 \\
\hline Nitzrect & 3 & -0.07 & 0.92 & 0.11 & 11.22 & -0.62 & -0.19 & -11.29 \\
\hline Nitzsubl & 3 & 0.10 & 11.58 & 0.10 & 10.56 & -0.74 & -0.34 & -11.88 \\
\hline Chlaspec & 4 & -0.22 & -0.35 & -0.19 & 0.08 & -0.37 & 0.16 & -0.10 \\
\hline Nitzfrut & 4 & 0.03 & 0.02 & -0.11 & 0.11 & -0.46 & 0.13 & -0.27 \\
\hline Pandmoru & 4 & 0.01 & 0.16 & -0.07 & 0.36 & -0.63 & -0.09 & -0.49 \\
\hline Schrrobu & 4 & -0.42 & 0.09 & -0.51 & 0.48 & -0.97 & -0.62 & -0.70 \\
\hline Schrseti & 4 & -0.13 & -0.32 & -0.24 & 0.26 & -0.59 & 0.27 & -0.29 \\
\hline Acanzach & 6 & -0.27 & -0.17 & -0.05 & -0.63 & 0.02 & -0.15 & 0.40 \\
\hline Euglacus & 6 & -0.01 & -0.05 & 0.06 & -0.26 & 0.06 & 0.27 & 0.28 \\
\hline Eugloxyu & 6 & -0.07 & -0.21 & -0.19 & -0.94 & 0.50 & 0.09 & 0.89 \\
\hline Eugltrip & 6 & 0.02 & -0.28 & -0.26 & -0.41 & 0.32 & 0.27 & 0.57 \\
\hline Navispec & 6 & -0.01 & -0.19 & 0.01 & -0.45 & 0.03 & 0.36 & 0.44 \\
\hline Asteform & 7 & 0.13 & -0.03 & 0.07 & 0.01 & 0.00 & 0.04 & -0.05 \\
\hline Aulaspec & 7 & 0.05 & -0.29 & -0.52 & -0.10 & 0.10 & -0.11 & 0.06 \\
\hline Cyclspec & 7 & 0.22 & -0.28 & -0.23 & -0.27 & 0.17 & 0.30 & 0.22 \\
\hline Cymbspec & 7 & 0.89 & -0.55 & -0.23 & -13.16 & 11.45 & 0.94 & 0.95 \\
\hline
\end{tabular}

The first 3 CCA axes were significant $(p<0.002)$ explaining $85.9 \%$ of the variance of the speciesenvironment relation and $27.7 \%$ of the species variance, respectively (Tab. 4).

Water age, DIN, and PIM is strongly correlating with the first axis, whereas Npart is mainly related to axis 2 (Fig. 5). Along the first axis groups can be arranged in three categories. Group 3 indicates the first category with very low water age and high amounts of PIM, Npart, Ppart, DIN and considering axis 3 (not shown) also DP. Category 2 comprises groups 1 and 4 to 7 , which are related to intermediate water age. Group 1 is characterized by high amounts of Npart whereas group 4, 6 and 7 show medium concentrations of Npart. Group 5 is very similar to group 4 and cannot be separated by the environmental variables used for CCA. On an average, group 6 is coinciding with higher water age, increased conductivity and lower concentrations of PM and nutrients. Group 2 indicates the third category with high water age, conductivity and low amounts of DIN, DP, PIM, POM and Chl- $a$.

The NMDS analyses of 1999 and 2003 data outline temporal trends of phytoplankton community similarity in the main channel D and the Regelsbrunn side-arm $\mathrm{R}$ (Fig. 7). During the high connectivity year 1999, temporal trends of phytoplankton similarity in the side-arm tracked closely the community patterns of the Danube. This suggests that the main channel had a major influ- ence on phytoplankton community structure during this year. In agreement with ISA analyses, the dominance of Nitzschia fonticola in the community throughout the sampling period suggests high connectivity between the main channel and the side-arm and a low water age at station R. Despite high connectivity, Pearson correlation between environmental variables with NMDS dimensions revealed different living conditions during this period (Tab. 6). NMDS 1 was negatively correlated with temperature and $\mathrm{pH}$ and positively related to conductivity, $\mathrm{O}_{2}$, alkalinity, and DIN fractions (Tab. 6). NMDS 2 correlated almost exclusively with fractions of $\mathrm{PM}$, thus reflecting a turbidity gradient. The variable water age did not correlate significantly with either NMDS dimension $(p>0.05)$.

During 2003, when the side-arm was more isolated from the main channel, the temporal trends of the communities from both sampling stations were less coupled. The ordination reflects three environmentally distinct periods which were dominated by different species (Fig. 7). The sampling periods with dominance of Cyclotella radiosa suggest intermediate water age, and therefore similar community dynamics at both sampling points were revealed as a result of hydrological disturbance. The phytoplankton succession was interrupted by a flood pulse that resulted in a shift of the community structure to a dominance of Nitzschia. After this event, the Danube community returned to its previous commu- 

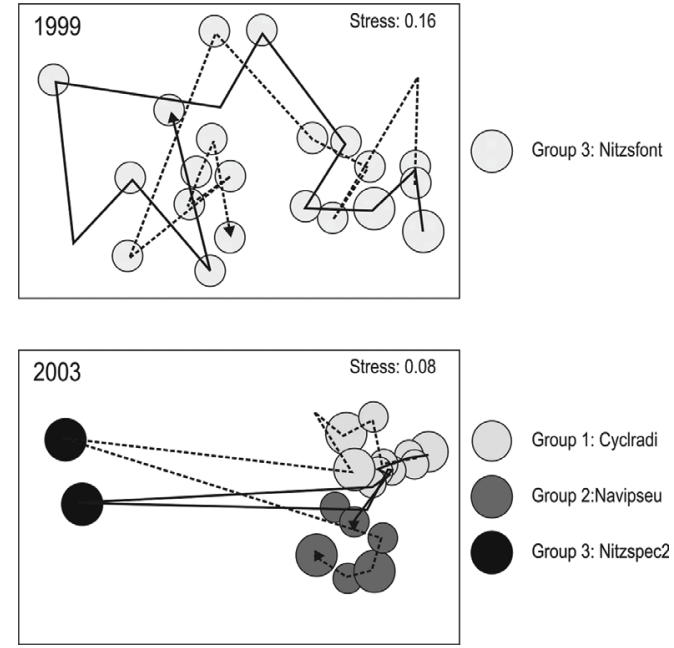

Fig. 7. Non-metric multidimensional scaling ordinations of phytoplankton communities from the Danube (full lines) and the Regelsbrunn backwater (dotted lines) for two years with contrasting connectivity (high in 1999 and low in 2003). Superimposed to the temporal trends are selected indicator species that reflect different environmental situations. The bubble plot option in Primer 6 has been used to highlight these species. The size of the bubbles reflects the relative abundance of these indicator species.

Tab. 6. Results form Pearson correlation analyses relating NMDS dimensions to environmental variables. Listed are the correlation coefficients and significance levels $(* p<0.05, * * p<0.01$, *** $p$ $<0.001)$

\begin{tabular}{|c|c|c|c|c|}
\hline \multirow[b]{2}{*}{ Variables } & \multicolumn{2}{|c|}{1999} & \multicolumn{2}{|c|}{2003} \\
\hline & NMDS 1 & NMDS 2 & NMDS 1 & NMDS 2 \\
\hline Temperature & $-0.82 *$ & & & $-0.53 *$ \\
\hline $\mathrm{pH}$ & $-0.58^{*}$ & & $0.65^{* *}$ & \\
\hline Conductivity & $0.49^{*}$ & & & \\
\hline $\mathrm{SiO}_{2}$ & & & & $-0.65^{* *}$ \\
\hline $\mathrm{O}_{2}$ & $0.57 *$ & & $0.49 *$ & $0.52 *$ \\
\hline Alkalinity & $0.43^{*}$ & & & \\
\hline $\mathrm{N}-\mathrm{NO}_{3}$ & $0.61 *$ & & & \\
\hline DON & $0.58^{*}$ & & & \\
\hline DIN & $0.61 *$ & & & \\
\hline $\mathrm{N}$-part & & $0.63 *$ & & $0.74 * * *$ \\
\hline P-part & & $0.55^{*}$ & & $0.63 * *$ \\
\hline POM & & & & $0.57 *$ \\
\hline RELPOM & & & & $0.59 *$ \\
\hline PM & & $0.54 *$ & & \\
\hline PON & & $0.57 *$ & & \\
\hline PIM & & $0.53 *$ & & \\
\hline Chl- $a$ & & & & $0.70^{* * *}$ \\
\hline
\end{tabular}

nity state, while the side-arm plankton diverged to a situation characterised by elevated isolation and water age, dominated by Navicula pseudanglica. The different environmental situations have also been captured by the correlation analysis (Tab. 6). NMDS 1 was positively correlated with $\mathrm{pH}$, alkalinity and chloride concentrations. NMDS 2 was correlated negatively with temperature and $\mathrm{SiO}_{2}$, and positively with $\mathrm{pH}, \mathrm{PM}$ and Chl- $a$. Again, the variable water age did not correlate significantly with either NMDS 1 or NMDS $2(p>0.05)$.

\section{DISCUSSION}

\subsection{Environmental variables}

Hydrological disturbances have major influence on both abiotic and biotic processes in riverine wetlands
(Mitsch \& Gosselink 2000). The restoration measures in the Regelsbrunn area, undertaken in 1998, led to an increased connectivity between the side-arm system and the main channel, which is reflected in contrasting lengths of isolation and connection phases (Hein et al. 1999; 2004a). Today, flood pulses cause an increased import of DIN and DP which on one hand improves the nutrient supply for phytoplankton but on the other hand contributes to a deterioration of the light climate as a result of elevated turbidity. The decrease of PIM during short isolation periods suggests a loss from the water column due to sedimentation, while decreasing amounts of POM are most likely caused by zooplankton grazing. With regard to the latter, similar observations have been made in other studies of the Danube and other temperate rivers (Van Den Brink et al. 1993; Tockner et al. 1999; 


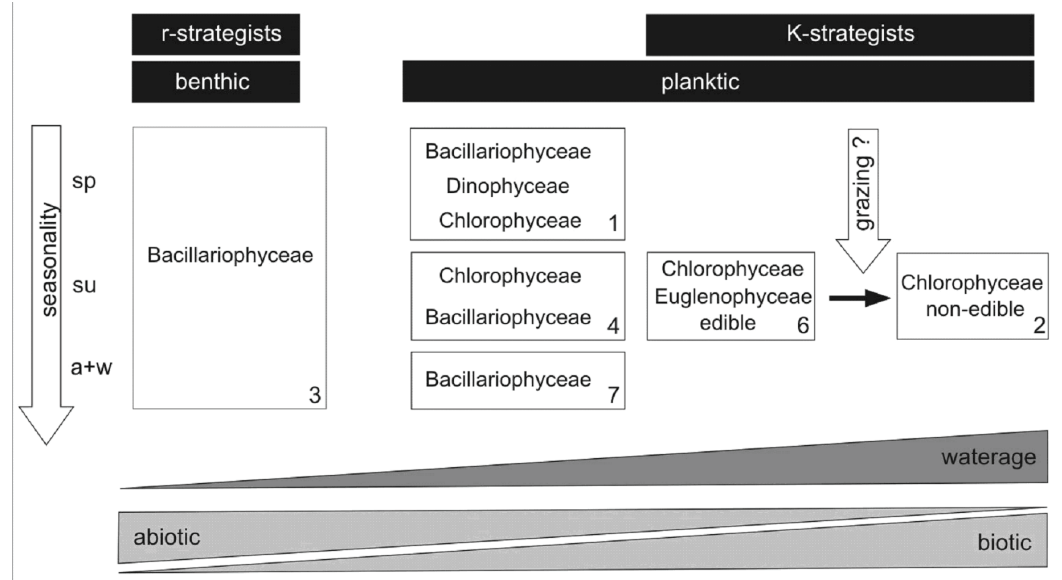

Fig. 8. Model of phytoplankton development showing the main factors controlling phytoplankton community of a temperate sidearm system. (sp) spring, (su) summer, (a) autumn, (w) winter, numbers indicate algal groups of CA and CCA.

Hein et al. 1999; 2004a; 2004b), which suggests that biotic feedback mechanisms can influence processes of ecosystems that otherwise, underlie strong abiotic regulation. Even though our study does not provide direct evidence for zooplankton control over water quality and phytoplankton, the influence of biotic processes in structuring communities is increasingly recognised in wetland ecology (Hanson et al. 2005; Scheffer et al. 2006), and may have even potential for management (Angeler et al. 2003).

\subsection{Phytoplankton biomass}

Due to the potential influence of many variables (light climate, nutrients, hydrology, competition and predation) on potamoplankton growth (Basu \& Pick 1996; Chetelat et al. 2006), algal biomass may express a complex pattern. In our study, Chl- $a$ showed low amounts during flood events because of dilution (Fig. 3). Likewise suboptimal light supply may also have constrained algal growth. During initial stages of isolation (up to $27 \mathrm{~d}$ of disconnection), algae were able to grow vigorously. Prolonged water age led to a decrease of algal biomass, probably as a result of zooplankton grazing (Gosselain et al. 1994). Keckeis et al. (2003) have highlighted that top-down control of zooplankton grazing increases after isolation periods of $10 \mathrm{~d}$ and peaks at water ages of approximately $17 \mathrm{~d}$ leading to a collapse of phytoplankton standing stock in Danubian backwaters. Additionally, nutrient limitation and sedimentation processes may have contributed to a decrease of algal biomass.

\subsection{Phytoplankton community structure}

The multivariate analyses showed that low water age is a primary determinant of the phytoplankton community structure in the side-arm system of Regelsbrunn, leading to a dominance of Bacillariophyceae, a typical component of temperate river potamoplankton (Descy 1993; Rojo et al. 1994; Gosselain et al. 1994). How- ever, during phases of moderate connection or isolation seasonality gained importance, as could be found in temperate lakes (Sommer et al. 1986; Lampert \& Sommer 1999), and allowed other algal groups to increase (e.g.: Chloro-, Dino- and Cryptophyta). Cyanoprokaryota are usually not well represented in the potamoplankton because of their low metabolic flexibility which limits acclimation to rapidly and strongly changing conditions (Gosselain et al. 1994).

Despite the importance of water age for structuring the phytoplankton community in this channel - side arm system, this variable was not significantly related to the temporal patterns of similarity in the NMDS analyses. Because our aims were to track phytoplankton community similarity between both sampling sites, we also included water age from both the side arm and the river channel in the subsequent correlation analyses. Because the values for the Danube were low throughout the study, they may have swamped the effect of this variable from the backwater, leading to insignificant correlations. Notwithstanding, the hydrology mediated changes in the environmental variables were well captured by the correlation analyses, highlighting the importance of hydrology, albeit indirectly, for phytoplankton dynamics in this system. This is also reflected by the distribution of indicator species in the ordination during different environmental situations for each study year.

Based on taxa occurrences, seven groups with contrasting environmental characteristics and community composition could be found (Fig. 4), for which we developed a model (Fig. 8). Group 3 (1999 data) showed typical abiotic and biotic properties of large temperate rivers (Descy 1993; Rojo et al. 1994; Gosselain et al. 1994) with very low water age, high nutrients and PIM concentrations, and impoverished light conditions. $88 \%$ of the species indicative for this group were represented by Bacillariophyceae (Nitzschia, Navicula, Cymbella, Fragilaria and Diatoma). Some species with the highest indicator values (Nitzschia dissipata, N. fon- 
ticola, $N$. linearis, $N$. recta and $N$. sublinearis) are typical benthic species which are resuspended during flood pulse events. Already Liepolt (1961) pointed out, that benthic flora may act as a seed bank for phytoplankton communities of large rivers. These species are apparently well adapted to low irradiances caused by high turbidity and they can cope with disturbances that lead to a decrease of population density. With maximum metabolic rates and short generation times, these $r$ strategists (Reynolds 1994; Garcia de Emilani 1997; Schagerl et al. 2004) gain maximum growth rates by optimizing resource use (Lampert \& Sommer 1999; Reynolds 1988).

Group 2 (summer 2003) displays features characteristic of floodplain lakes (Van den Brink et al. 1993) with enduring isolation, elevated water age, increased electrical conductivity, and low concentrations of DOM, POM and phytoplankton biomass (Tab. 5). The low phytoplankton standing crop may be due to sedimentation, competition for nutrients, and zooplankton grazing (Keckeis et al. 2003). Zooplankton biomass usually increases during prolonged isolation (Basu \& Pick 1996) as a result of their slower colonization and reproduction times (Baranyi et al. 2002). Among the indicator species, around $40 \%$ Chlorophyta contributed to group 2. Almost all of them are euplanktic and show growth optima at high water age, coupled with low nutrient concentrations and decreased algal biomass. As $\mathrm{K}$-strategists, they seem to be able to optimize resource use at lower nutrient concentrations (Lampert \& Sommer 1999). Several planktonic species (Scenedesmus and Pediastrum) typically form coenobia with long appendices or gelatinous sheaths which serve as a morphological protection mechanism against zooplankton grazing (Lampert \& Sommer 1999).

Group 6 (summer to autumn 1997 and 1998) is also typical for isolated side-arms, but differs from group 2 by a shorter period of isolation and increased values of phytoplankton biomass. Two thirds of group 6 indicator species were euplanktic members of Chlorophyta (Pediastrum duplex), Bacillariophyceae (Acanthoceras zachariasii) and Euglenophyta (E. acus, E. oxyuris, E. tripteris). These species share the same environmental requirements as members of group 2; however, they are less adapted to sedimentation and zooplankton grazing that increase with prolonged water age (Keckeis et al. 2003).

Groups 1, 4, 5 and 7 are connecting groups 2 and 3. They are characterised by a moderate change of connection and isolation. Rather than being separated by environmental characteristics, these groups are split on the basis of seasonality. Common features are their sensitivity against high turbulences and impoverished light climate and a higher nutrient demand for growth. Moreover, intermediate disturbances are needed to avoid zooplankton-inflicted mortality (Keckeis et al. 2003). The importance of seasonality in these groups is reflected in the first appearance of group 1 in early spring when phytoplankton densities are generally low. This group comprises $50 \%$ of planktonic centric diatoms (e.g., Cyclotella radiosa, Stephanodiscus minutulus, S. medius) and dinophyceaen (Peridinium sp., Gymnodinium sp.), chlorophyceaen (Chlamydomonas sp.) and chrysophyceaen flagellates (Synura sp.). Also some benthic diatoms could be found during this period. Group 4 occurring from May to July contained planktonic members of the Chlorophyta (Chlamydomonas sp., Pandorina morum, Schroederia robusta, S. setigera) and diatoms (Nitzschia fruticosa). Sampling dates were characterized by highest population densities. During this time, $r$-strategists lost their importance and were replaced by species with lower maximum growth rates, but more efficient nutrient uptake (compare Lampert \& Sommer 1999). Because some occurring species were not edible for zooplankton, grazing apparently had not played a major role during this period.

Group 7 is typically found in autumn and winter; this period is characterised by lower concentration of POM and Chl- $a$ compared to group 4. However, the indicator species (Asterionella formosa, Aulacoseira sp., Cyclotella sp.) had a low specificity and these taxa were also found in several other groups at intermediate to high water age.

\section{CONCLUSIONS}

While hydroperiods and flood frequency have received much attention from wetland ecologists for characterising hydrological disturbance regimes and their influence on biotic and abiotic processes (Mitsch $\&$ Gosselink 2000), our study highlights the relevance of water age, which depends on, but is not necessarily equivalent to, the aforementioned features, as a major factor regulating phytoplankton communities in floodplains of large rivers (Fig. 8). Flood pulses control phytoplankton composition strongly due to hydrological disturbance and linked changes in the abiotic environment. During very long periods of connection, seasonality has hardly any effect on phytoplankton which is dominated by benthic forms and fast-growing $r$-strategists that are resuspended from the sediment. During situations of moderate connection and higher water age, other algal classes gain importance and the phytoplankton is increasingly dominated by euplankton and flagellates, and $K$-strategists that differ in community composition according to water age. Thus shifts in community structure due to succession are an important factor to consider in studies of floodplain plankton ecology. Biotic interaction (i.e., the competition for nutrients and/or zooplankton grazing) could play an important role in inducing shifts between successional stages during prolonged periods of isolation. Although biotic interaction has been hardly considered in the study of disturbed ecosystems, there exists increasing evidence about their feedback effects on structural and functional 
wetland properties. Future research should consider these effects to better understand biological processes within the constraints set by riverine disturbance regimes.

\section{ACKNOWLEDGEMENTS}

This project was funded by the Austrian Committee of the International Association for Danube Research (AC-IAD), the Alluvial Zone National Park and the Austrian Science Fund (grant \# P11720 bio). Hydrological data and TSS concentrations for the main channel were provided by the Austrian River Authority. Alan Steel provided the program to calculate the water age with which to quantify the hydrological connectivity.

\section{REFERENCES}

Anagnostidis, K. \& J. Komarek. 1988. Modern approach to the classification system of cyanophytes, 3 - Oscillatoriales. Arch. Hydrobiol. Suppl. Algol. Stud., 80: 327-472.

Angeler, D.G., P. Chow-Fraser, M.A. Hanson, S. SanchezCarrillo \& K.D. Zimmer. 2003. Biomanipulation: a useful tool for freshwater wetland mitigation? Freshwat. Biol., 48: 2203-2213.

A.P.H.A., 1995. Standard methods for the Examination of Water and Wastewater. American Public Health Association, Washington D. C., U. S. A., 19th Edition.

Baranyi, C., T. Hein, C. Holarek, S. Keckeis \& F. Schiemer. 2002. Zooplankton biomass and community structure in a Danube River floodplain system: effects of hydrology. Freshwat. Biol., 47: 473-482.

Basu, B.K. \& F.R. Pick. 1996. Factors regulating phytoplankton and zooplankton biomass in temperate rivers. Limnol. Oceanogr., 41: 1572-1577.

Bayley, P.B. 1991. The flood pulse advantage and the restoration of river-floodplain systems. Regul. Riv., 6: 75-86.

Bayley, P.B. 1995. Understanding large river-floodplain ecosystems. BioScience, 45, 153-158.

Bourelly, P. 1970. Les algues d'eau douce. Tome III: Les algues bleues et rouges. Les Eugléniens, Peridiniens et Cryptomonadines. Ed. Boubée, Paris.

Chetelat, J., F.R. Pick \& P.B. Hamilton. 2006. Potamoplankton size structure and taxonomic composition: Influence of river size and nutrient concentrations. Limnol. Oceanogr., 51: 681-689.

Descy, J.P. 1993. Ecology of the phytoplankton on the River Moselle: effects of disturbances on community structure and diversity. Hydrobiologia, 249: 111-116.

Dufréne, M. \& P Legendre. 1997: Species assemblages and indicator species: the need for a flexible asymmetrical approach. Ecological Monographs, 67: 345-366.

Ettl, H. 1983. Chlorophyta I. In: H. Ettl, J. Gerloff, H. Heynig \& D. Mollenhauer. (Eds), Süßwasserflora von Mitteleuropa.. Band 9. G. Fischer Verlag: 807pp

Garcia de Emiliani, M.O. 1997. Effects of water level fluctuations on phytoplankton in a river-floodplain lake system (Paraná River, Argentina). Hydrobiologia, 357: 1-15.

Geitler, L. 1932. Cyanoprokaryota. In: R. Kolkwitz (Ed.), Die Algen. Dr. L. Rabenhorst's Kryptogamen-Flora von Deutschland, Österreich und der Schweiz, 14. Band, 2nd Ed., reprint 1985. Koeltz Scientific Books: 1196 pp.

Golterman, H.L., R.S. Clymo \& M.A.M. Ohnstad. 1978. Methods for physical and chemical analysis of freshwater. Oxford, Blackwell Scientific.

Gosselain, V., J.P. Descy \& E. Everbecq. 1994. The phytoplankton community of the River Meuse, Belgium: sea- sonal dynamics (year 1992) and the possible incidence of zooplankton grazing. Hydrobiologia, 289: 179-191.

Gruberts, D., I. Druvietis, E. Parele, J. Paidere, A. Poppels, J. Prieditis \& A. Skute. 2007. Impact of hydrology on aquatic communities of floodplain lakes along the Daugava River (Latvia). Hydrobiologia, 584: 223-237

Hanson, M. A., K.D. Zimmer, M.G. Butler, B.A. Tangen, B.R. Herwig \& N.H. Euliss Jr. 2005. Biotic interactions as determinants of ecosystem structure in prairie wetlands: an example using fish. Wetlands, 25: 764-775.

Hein, T., C. Baranyi, G.J. Herndl, W. Wanek \& F. Schiemer. 2003. Allochthonous and autochthonous particulate organic matter in floodplains of the River Danube: the importance of hydrological connectivity. Freshwat. Biol., 48: 220-232.

Hein, T., C. Baranyi, W. Reckendorfer \& F. Schiemer. 2004a. The impact of surface water exchange on the nutrient and particle dynamics in side-arms along the River Danube, Austria. Sci. Tot. Environ., 328: 207-218.

Hein, T., C. Baranyi \& W. Reckendorfer. 2004b. Einfluss von Öffnungsmaßnahmen auf die hydrochemische Situation und die planktischen Prozesse in einem dynamischen $\mathrm{Au}-$ system. Abh. Zool.-Bot. Ges. Österreich, 34: 31-46.

Hein, T., G. Heiler, D. Pennetzdorfer, P. Riedler, M. Schagerl \& F. Schiemer. 1999. The danube restoration project: functional aspects and planktonic productivity in the floodplain system. Reg. Riv. Res. Manag., 15: 259-270.

Höhn, E., H.A.M. Ketelaars \& B. Ewig. 1998. Erfassung und Bewertung von Planktonorganismen. 2. neu bearbeitete Auflage. R. Oldenbourg Verlag, München.

Huber-Pestalozzi, G. 1955. Das Phytoplankton des Süßwassers, Systematik und Biologie, 4. Teil: Euglenophyceen. In: A. Thienemann (Ed.), Die Binnengewässer, Band 16, 4. Teil. E. Schweizbart'sche Verlagsbuchhandlung, Stuttgart: $606 \mathrm{pp}$

Jenkins, K.M. \& A.J. Boulton. 2003. Connectivity in a dryland river: Short-term aquatic microinvertebrate recruitment following floodplain inundation. Ecology, 84: 2708-2723.

Jenkins, K.M. \& A.J. Boulton. 2007. Detecting impacts and setting restoration targets in arid-zone rivers: aquatic micro-invertebrate responses to reduced floodplain inundation. J. Appl. Ecol., 4: 823-832.

Johnson, B.L., B.R. Richardson \& T.J. Naimo. 1993. Past, Present and Future Concepts in Large River Ecology. BioScience, 45: 3 .

Junk, W.J., P.B. Bayley \& R.E. Sparks. 1989. The flood pulse concept in river-floodplain systems. Proc. Internat. Large River Symp. Canadian Special Publications of Fisheries and Aquatic Sciences. NRC Research Press, Ottawa, Canada: 110-121.

Junk, W.J. \& K.M. Wantzen. 2004. The Flood Pulse Concept: New Aspects, Approaches, and Applications - an Update. Proc. Second Internat. Symp.Manag. Large Riv. Fish., R. L. Welcomme and T. Petr. Bangkok, FAO., 2: 117-149.

Keckeis, S., C. Baranyi, T. Hein, C. Holarek, P. Riedler \& F. Schiemer. 2003. The significance of zooplankton grazing in a floodplain system of the River Danube. J. Plankton Res., 25: 243-253

Komarek, J. \& B. Fott. 1983. Chlorophyceae (Grünalgen), Ordnung: Chlorococcales. In: G. Huber-Pestalozzi (Ed.), Das Phytoplankton des Süßwassers, Heft 7/1. Schweitzerbart'sche Verlagsbuchhandlung, Stuttgart: 1044pp.

Komarek, J. \& K. Anagnostidis 1999. Cyanoprokaryota. 1. Teil Chroococcales. In: H. Ettl, G. Gärtner, H. Heynig \& G. Anagnostidis (Eds), Süßwasserflora von Mitteleuropa, Band 19/1. G.Fischer Verlag, Stuttgart - New York: 548pp.

Krammer, K. \& H. Lange-Bertalot. 1986. Bacillariophyceae, Teil 1: Naviculaceae. In: H. Ettl, J. Gerloff, H. Heynig, \& D. Mollenhauer (Eds), Süßwasserflora von Mitteleuropa, Band 2/1. G. Fischer Verlag, Stuttgart - New York: 876 pp. 
Krammer, K. \& H. Lange-Bertalot. 1988. Bacillariophyceae, Teil 2: Bacillariaceae, Epithemiaceae, Surirellaceae. In: H. Ettl, J. Gerloff, H. Heynig, \& D. Mollenhauer (Eds), Süßwasserflora von Mitteleuropa,., Band 2/2. G. Fischer Verlag, Stuttgart - New York: 596 pp.

Krammer, K. \& H. Lange-Bertalot. 1991a. Bacillariophyceae, Teil 3: Centrales, Fragilariaceae, Eunotiaceae. In: H. Ettl, J. Gerloff, H. Heynig, \& D. Mollenhauer (Eds), Süßwasserflora von Mitteleuropa, , Band 2/3. G. Fischer Verlag, Stuttgart - New York: 576 pp.

Krammer, K. \& H. Lange-Bertalot. 1991b. Bacillariophyceae, Teil 4: Achnanthaceae, Kritische Ergänzungen zu Navicula (Lineolatae) und Gomphonema. In: H. Ettl, J. Gerloff, H. Heynig, \& D. Mollenhauer (Eds), Süßwasserflora von Mitteleuropa, Band 2/4. G. Fischer Verlag, Stuttgart New York: $437 \mathrm{pp}$.

Kusel-Fetzmann, E. 2002. Die Euglenophytenflora des Neusiedler Sees (Burgenland, Österreich). Abh. Zool.-Bot. Ges. Österreich, 32: 1-115.

Lampert, W. \& U. Sommer. 1999. Limnoökologie. Georg Thieme Verlag, Stuttgart - New York.

Liepolt, R. 1961. Limnologische Forschungen im österreichischen Donaustrom. Verh. Internationale Ver. Theoret. Angew. Limnol., 14: 422-429.

Limberger R., C. Fesl \& M. Schagerl. 2004. Phytoplankton community structure in a Danubian backwater system: Response to environmental factors. Arch. Hydrobiol., 161: 181-198.

Lorenzen, C.J. 1967. Determination of chlorophyll and pheopigments: spectrophotometric equations. Limnol. Oceanogr., 12: 343-346.

Mc Cune, B. \& J.B. Grace. 2002. Analysis of Ecological Communities. MjM Software Design, Gleneden Beach, Oregon.

Mc Cune B. \& M.J. Mefford. 1999. PC-ORD for Windows, Multivariate Analysis of Ecological Data, Version 4.25. MjM Software, Gleneden Beach, Oregon U.S.A.

Middleton, B.A. 1999. Wetland restoration, flood pulsing and disturbance dynamics. New York, John Wiley and Sons.

Mitsch, W. J. \& J.G. Gosselink. 2000. Wetlands. 3rd edition. John Wiley and Sons, New York.

Popovsky, J. \& L. Pfiester. 1990. Dinophyceae. In: H. Ettl, J. Gerloff, H. Heynig, \& D. Mollenhauer (Eds), Süßwasserflora von Mitteleuropa, Band 6. G. Fischer Verlag: 272 pp.

Reynolds, C.S. 1988. Functional morphology and the adaptive strategies of freshwater phytoplankton. In: C.D. Sandgren (Ed.), Growth and Reproductive Strategies of Freshwater Phytoplankton.. Cambridge University Press, Cambridge: 388-433.

Reynolds, C.S. 1994. The long, the short and the stalled: on the attributes of phytoplankton selected by physical mixing in lakes and rivers. Hydrobiologia, 289: 9-21.

Rojo, C., C. Alvarez \& M. Arauzo. 1994. An elementary structural analysis of river phytoplankton. Hydrobiologia, 289: 43-55.

Schagerl, M. 1993. Ausgewählte Untersuchungen an Algen aus den Gebieten der Systematik, Physiologie und Ökologie. Dissertation Universität Wien.

Schagerl, M., H. Krbec, S. Nairz \& C. Wieltschnig. 1996. Pelagische Primärproduktion in einem Donaualtarm bei Regelsbrunn (Niederösterreich). Verh. Zool.-Bot. Ges. Österreich, 133: 201-216.

Schagerl, M. \& K. Donabaum. 2003. Patterns of major photosynthetic pigments in freshwater algae. 1. Cyanoprokaryota, Rhodophyta and Cryptophyta. Internat. J. Limnol., 39: 35-47.

Schagerl, M., C. Pichler \& K. Donabaum. 2003. Patterns of major photosynthetic pigments in freshwater algae. 2. Di- nophyta, Euglenophyta, Chlorophyceae and Charales. Internat. J. Limnol., 39: 49-62.

Schagerl, M., P. Riedler \& A. Wittmann. 2004. Der Einfluss der Öffnungsmaßnahmen auf die Phytoplanktongemeinschaft im Regelsbrunner Altarm. Abh. Zool.-Bot. Ges. Österreich, 34: 47-66.

Scheffer, M., G.J. van Geest, K. Zimmer, E. Jeppesen, M. Sondergaard, M.G. Butler, M.A. Hanson, S. Declerck \& L. De Meester. 2006. Small habitat size and isolation can promote species richness: second-order effects on biodiversity in shallow lakes and ponds. Oikos, 112: 227-231.

Schiemer, F., C. Baumgartner \& K. Tockner. 1999. Restoration of floodplain rivers: The Danube Restoration Project. Reg. Riv. Res. Manag., 15: 231-244.

Soma, Y., T. Imaizumi, K. Yagi \& S. Kasuga. 1993. Estimation of algal succession in lake water using HPLC analysis of pigments. Can. J. Fish. Aquat. Sci., 50: 1142-1146.

Sommer, U., Z.M. Gliwicz, W. Lampert \& A. Duncan. 1986. The PEG-model of seasonal succession of planktonic events in fresh waters. Arch. Hydrobiol., 106: 433-471.

Starmach, K. 1985. Chrysophyceae und Haptophyceae. In: H. Ettl, J. Gerloff, H. Heynig, \& D. Mollenhauer (Eds), Süßwasserflora von Mitteleuropa, Band 1. G. Fischer Verlag: $515 \mathrm{pp}$.

Strickland, J.D.H. \& T.R. Parsons. 1972. A practical handbook of seawater analysis., Bull. 167 Fisheries Research Bd. Canada.

Tockner, K., D. Pennetzdorfer, N. Reiner, F. Schiemer \& J.V. Ward. 1999. Hydrological connectivity, and the exchange of organic matter and nutrients in a dynamic river-floodplain system (Danube, Austria). Freshwat. Biol., 41: 521535.

Tockner, K. \& J.A. Stanford. 2002. Riverine flood plains: present state and future trends. Environ. Cons., 29: 1-10.

ter Braak, C.J.F. 1995. Ordination. In: R.H.G. Jongman, , C.J.F. ter Braak, \& O.F.R. van Tongeren(Eds), Data analysis in community and landscape ecology. Cambridge University Press: Cambridge, UK: 91-173

ter Braak, C.J.F. \& P. Smilauer. 2002. CANOCO for Windows 4.5. Biometris - Plant Research International, Wageningen, The Netherlands.

Utermöhl, H. 1958. Zur Vervollkommnung der quantitativen Phytoplanktonmethodik. Mitt. Internat. Verein. Limnol., 9: 1-38.

Van den Brink, F.W.B., J.P.H.M. de Leeuw, G. Van der Velde \& G.M. Verheggen. 1993. Impact of hydrology on the chemistry and phytoplankton development in floodplain lakes along the Lower Rhine and Meuse. Biogeochemistry, 19: 103-128.

Vannote, R.L., G.W. Minshall, K.W. Cummins, J.R. Sedell \& C.E. Cushing. 1980. The river continuum concept. Can. J. Fish. Aquat. Sci., 37: 130-137.

Wilhelm, C., I. Rudolph \& W. Renner. 1991. A quantitative method based on HPLC-aided pigment analysis to monitor structure and dynamics of the phytoplankton assemblage A study from Lake Meerfelder Maar (Eifel, Germany). Arch. Hydrobiol., 123, 21-35.

Wittmann, A. 2001. Primärproduktion und Algengemeinschaften im Regelsbrunner Altarm und im Donaustrom Untersuchungen nach der Altarmöffnung. Diplomarbeit Universität Wien.

Wright, S.W., S.W. Jeffrey, R.F.C. Mantoura, C.A. Llewellyn, T. Bjornland, D. Repeta \& N. Welschmeyer. 1991. Improved HPLC method for the analysis of chlorophylls and carotenoids from marine phytoplankton. Mar. Ecol. Prog. Ser., 77: 183-196.

Received: September 2008

Accepted: April 2009 